\title{
ALTERNATIF KEBIJAKAN MENGHADAPI PERGOLAKAN PETAMBAK AKIBAT PENCEMARAN PERAIRAN (Studi Kasus Pada Petambak Ujung Pangkah Kabupaten Gresik)
}

\author{
Policy Options to Deal With : \\ Fish Farmers Upheaval Due Water Pollution \\ (Case Study on Ujung Pangkah Fish Farmers of Gresik Regency)
}

\author{
Istiana \\ Balai Besar Penelitian Sosial Ekonomi Kelautan dan Perikanan \\ JI. KS. Tubun Petamburan VI Jakarta 10260 \\ Telp. (021) 53650162, Fax. (021)53650159 \\ Email: isti0112@yahoo.com \\ Diterima 11 Maret 2013 - Disetujui 31 Mei 2013
}

\begin{abstract}
ABSTRAK
Tujuan penelitian ini adalah untuk mendiskripsikan pergolakan yang terjadi pada masyarakat petambak sebagai akibat adanya pencemaran perairan. Penelitian ini dilakukan pada bulan Juli 2011 sampai Januari 2013 di desa Pangkah Wetan Kecamatan Ujung Pangkah Kabupaten Gresik. Penelitian ini menggunakan tipe penelitian deskriptif-kualitatif. Jenis penelitian ini adalah studi kasus (case study) yang memusatkan pada kelompok masyarakat petambak. Teknik pemilihan informan secara purposive. Pengumpulan data primer dilakukan dengan cara indepth interview. Analisis data dilakukan secara deskritif kualitatif. Hasil penelitian menunjukkan bahwa akibat pencemaran perairan, petambak mengalami penurunan pendapatan. Petambak menuduh tercemarnya lingkungan pesisir berasal PT. Hess Indonesia Ltd. karena memang cuma satu-satunya perusahaan itu yang ada di desa. Kondisi ini telah memunculkan kebersamaan petambak dengan melalui interaksi informal antar petambak yang memunculkan kelompok tani tambak desa Pangkah Wetan. Solidaritas kolektif komunitas memobilisasi gerakan pertentangan yang efektif dalam melahirkan kekuatan menggerakkan massa yaitu gerakan terbuka atau unjuk rasa dengan komunitas masyarakat petambak dan nelayan desa lain. Aksi protes yang dilakukan petambak merupakan bentuk resistensi petambak terhadap kebijakan pemerintah dan pengusaha. Gerakan ini bukan sekedar suatu reaksi tetapi juga sebagai wahana untuk mencapai tujuan-tujuan perubahan yaitu lingkungan tambak yang memiliki daya dukung tinggi.
\end{abstract}

Kata Kunci: pergolakan petambak, gerakan sosial, Kabupaten Gresik

\begin{abstract}
The aims of the study is to describe the upheaval in fish farmers community as a result of water pollution. Research was conducted during July 2011 to January 2013 in Pangkah Wetan Village Ujung Pangkah District of Gresik Regency. The research type were qualitative descriptive. The research is a case study which focus on the fish farmer community groups. Informants were selected purposively. Primary data were collected by using in-depth interview. Result of the research showed that due to water pollution, fish farmers have complained about declining income. Fish farmers were predict that coastal environmental contamination derived main company, namely PT. Hess Indonesia Ltd. This situation has led to fish farmers togetherness through informal interactions among fish farmers. Collective solidarity of communities has been mobilize effective opposition movement, namely demonstration did by fish farmer against government policy and private company. This protest is not only a reaction but also the way to achieve the objectives of environmental changes of brackish water pond that have a high carrying capacity.
\end{abstract}

Keywords: upheaval fish farmers, social movements, Gresik Regency 


\section{PENDAHULUAN}

Kebijakan pemerintah yang memberikan kesempatan PT. Hess Indonesia Ltd. untuk mengeksplorasi migas di blok Ujung Pangkah telah memunculkan pergolakan di masyarakat petambak dan nelayan. Mereka merasakan dampak buruk bagi masyarakatnya yang sebagian besar bertumpu pada sumberdaya perairaan yaitu nelayan dan petambak. Hess corporation merupakan perusahaan swasta internasional yang bergerak dalam bidang eksplorasi dan produksi minyak mentah dan gas alam serta mengolah dan memasarkan produk-produk tersebut. Salah satu perusahaan Hess corporation yang ada di Indonesia adalah Hess (Indonesia-Pangkah), Ltd. Blok Pangkah berlokasi di daerah pesisir lepas pantai utara Gresik-Jawa Timur. Hess (IndonesiaPangkah), Ltd merupakan lahan produksi yang dikembangkan menjadi tiga fasilitas produksi yaitu LPGF (Liquified Petroleum Gas Facilities), GPF (Gas Petroleum Facilities), dan OTF (Oil Treatment Facilities). Produk yang dihasilkan oleh HESS (Indonesia-Pangkah) Ltd adalah light sweet oil dan LPG (Liquified Petroleum Gas) yang dikirim ke konsumen melalui kapal tanker melewati perairan pantai utara, serta produk sales gas yang langsung dijual ke PJB Gresik. Perusahan ini telah diresmikan langsung oleh Presiden pada bulan Mei 2007.

Keberadaan perusahaan migas ini menjadi ancaman bagi keberlanjutan usaha tambak dan nelayan. Hal ini terbukti pada pemberitaan suara karya, hari selasa (30 Oktober 2007), menyebutkan telah terjadi pencemaran air laut akibat tumpahan minyak mentah. Begitu juga pada tanggal 1 November 2012, UM (nelayan yang sekaligus sekretaris HSNI cabang Gresik) mengetahui bahwa ada ceceran limbah minyak yang timbul di permukaan laut pada saat dia akan melakukan penangkapan ikan. Kejadian tersebut terjadi di tengah laut pada pukul 03.45 WIB. Karena ada limbah minyak, UM membatalkan kegiatan penangkapan ikan, dia memilih kembali kedaratan dan melaporkan pada ketua HSNI (Himpunan Nelayan Seluruh Indonesia) cabang Gresik.

Gabungan nelayan dan Petambak kecamatan Ujung Pangkah, Sidayu dan Panceng menuding bahwa pencemaran laut tersebut berasal dari pengeboran minyak dan gas milik PT. Hess Indonesia Pangkah. Tudingan itu muncul karena perusahaan pengeboran asal Amerika Serikat ini satu-satunya yang memiliki lokasi pengeboran off shore (lepas pantai) atau rig di perairan Ujung Pangkah. Selain itu Harian Surya (tanggal 9 November 2012) juga mengabarkan bahwa nelayan, petambak dan tokoh masyarakat Ujung Pangkah, Gresik mengadu ke Pemerintah Kabupaten (Pemkab) Gresik terkait kerusakan lingkungan dan ikan mati. Mereka menuding tumpahan minyak berasal dari eksplorasi PT Hess Indonesia - Pangkah Ltd. Berita Gresik \& Jawa Timur tanggal 2 November 2012 memberitakan bahwa dampak pencemaran minyak di Gresik di Perairan Ujung Pangkah mulai mengganggu ekosistem biota laut. Ribuan ekor rajungan atau kepiting laut dan ikan muara di sekitar lokasi off shore PT. Hess Indonesia Pangkah (HEI) diketahui mati.

Pantai utara di kabupaten Gresik merupakan sumber mata pencarian bagi nelayan dan petambak. Pantai ini pula yang mengairi seluruh tambak di wilayah Gresik. Secara geografis, Gresik memiliki luas wilayah laut mencapai $5.773,8 \mathrm{~km}^{2}$ dan wilayah daratan hanya $1.192 \mathrm{~km}^{2}$. Sepertiga wilayah Gresik merupakan pesisir pantai dengan panjang pantai 140 kilometer terbentang mulai Kecamatan Kebomas, Gresik, Bungah, Panceng dan Ujungpangkah. Selain sebagai kota pantai Gresik juga menjadi kota industri, yang memberi kontribusi terhadap pencemaran perairan di Gresik (BPS Gresik, 2011). Tercemarnya perairan Gresik sangat dirasakan nelayan dan petambak. Keberadaan ikan-ikan di laut Gresik mulai berkurang. Budidaya tambak juga tidak maksimal lagi karena daya dukung tambak terus menurun. Ancaman kerusakan ekosistem perairan pantai Gresik membayangi kehidupan para petambak dan nelayan. Kerusakan ekosistem tentunya akan berdampak pada penurunan usaha. Padahal menurut Paige (2004), tanah merupakan satu-satunya penentu utama kesejahteraan. Pada masyarakat petambak, tambak merupakan penentu kesejahteraannya. Jika tambak mengalami masalah dimana tambak merupakan sumber utama penghasilan, maka akan menghilangkan sumber kehidupan mereka.

Kondisi perairan yang tercemar akan menimbulkan kegelisahan-kegelisahan komunitas petambak dalam kehidupannya dengan adanya gangguan produktivitas usaha budidayanya. Keresahan dan ketidak-nyamanan kehidupan petambak karena ada 'gangguan' dalam usaha tambak mereka yang merupakan sumber penghasilannya. Tentunya ada akibat dari timbulnya kegelisahan yaitu gerakan-gerakan petambak (gerakan sosial). Gerakan sosial para 
petambak menunjukkan bahwa masyarakat menghendaki perbaikan kehidupan. Pencetus Teori Interaksionisme Simbolik, Herbert Blumer, menyatakan gerakan sosial sebagai suatu kegiatan bersama untuk menentukan suatu tatanan baru dalam kehidupan. Kemunculan gerakan sosial ditandai adanya kegelisahan akibat kesenjangan antara nilai-nilai harapan dan kenyataan hidup sehari-hari. Oleh karena itu, suatu kelompok masyarakat mendambakan tatanan hidup yang baru, dengan membentuk sebuah gerakan yang terorganisir. Fenomena pergolakan yang muncul pada masyarakat petambak perlu dikaji dengan tujuan untuk mendiskripsikan pergolakan yang terjadi pada masyarakat petambak akibat adanya pencemaran perairan lingkungan tambak.

\section{METODOLOGI}

\section{Waktu dan Lokasi Penelitian}

Penelitian ini dilakukan pada bulan Juli 2011 sampai Januari 2013 di desa Pangkah Wetan Kecamatan Ujung Pangkah Kabupaten Gresik. Alasan pemilihan lokasi penelitian ini adalah banyaknya jumlah petambak yang bermukim di kecamatan ini, sekitar $38,67 \%$ dari total petambak air payau di kabupaten Gresik. Selain itu, lokasi penelitian juga berdekatan (berada pada satu kecamatan) dengan perusahaan migas PT Hess Indonesia - Pangkah Ltd.

\section{Jenis Penelitian}

Penelitian ini menggunakan penelitian tipe deskriptif-kualitatif. Jenis penelitian ini adalah studi kasus (case study) dimana penelitian ini memusatkan diri secara intensif pada satu obyek tertentu yaitu pada suatu kelompok masyarakat saja (masyarakat petambak). Menurut Mulyana (2004), studi kasus adalah uraian dan penjelasan komprehensif mengenai berbagai aspek seorang individu, suatu kelompok, suatu organisasi (komunitas), suatu program atau suatu situasi sosial. Kasus yang diangkat adalah tindakan yang dilakukan petambak akibat terjadinya kerusakan lingkungan tambak dan sekitarnya. Dengan mempelajari semaksimal mungkin realitas sosial masyarakat petambak, peneliti bertujuan memberikan gambaran atau penjelasan secara mendalam mengenai pergolakan yang terjadi pada masyarakat petambak.

\section{Subyek Penelitian dan Teknik Pemilihan Informan}

Informan dalam penelitian ini adalah petambak yang terlibat dalam gerakan sosial. Informan terbagi menjadi tiga kategori yaitu informan kunci, informan utama dan informan tambahan. Informan kunci yaitu informan yang diasumsikan mengetahui dan memberikan informasi yang dibutuhkan peneliti. Informan ini adalah ketua kelompok tani tambak desa Pangkah Wetan dan 3 orang ketua tani tambak kampung di desa tersebut. Informan utama (subyek) adalah sasaran utama dalam proses penelitian ini yang dapat memberikan informasi terkait tema penelitian. Mereka adalah petambak pemilik sekaligus penggarap yang lebih mengetahui kondisi lapangan (sebanyak 6 orang). Informan tambahan (non subyek) adalah informan yang memberikan data pendukung dalam penelitian ini diantaranya Kepala Desa Pangkah Wetan, Kepala Bidang Budidaya Dinas Kelautan, Perikanan dan Peternakan Kabupaten Gresik dan Ketua Tani Nelayan Desa Pangkah Wetan.

Teknik pemilihan informan yang dipakai dalam penelitian ini adalah purposive. Sebutan purposive menunjukan bahwa teknik ini digunakan untuk mencapai tujuan-tujuan tertentu. Tujuan dari penentuan subyek secara purposive adalah merinci kekhususan-kekhususan yang ada kedalam konteks yang unik dan bertujuan menggali informasi yang akan menjadi dasar dari rancangan dan teori yang muncul serta dengan pertimbangan-pertimbangan khusus yang relevan terhadap permasalahan yang dikaji dalam memilih subyek penelitian (Moleong, 2008). Pemilihan informasi dengan teknik ini membutuhkan kemampuan dan pengetahuan yang baik dari peneliti terhadap subyek penelitiannya. Dalam menetapkan siapa yang termasuk dalam subyek penelitiannya, peneliti harus benar-benar mengetahui dan beranggapan bahwa informan yang dipilihnya dapat memberikan informasi yang diinginkan sesuai dengan permasalahan penelitian. Seringkali purposive didasarkan atas informasi yang mendahului (previous knowledge) tentang keadaan informan. Informasi yang diperoleh tidak lagi meragukan, masih samar-samar, kira-kira atau masih berdasarkan dugaan-dugaan.

\section{Metode Pengumpulan Data dan Analisis Data}

Data primer dan sekunder penelitian ini berasal dari berbagai sumber dan semua pihak yang bersangkutan dengan kasus yang diangkat. 
Pengumpulan data primer dilakukan dengan cara indepth interview dan wawancara terbuka yang lebih menyerupai bentuk dialog bebas. Data yang telah dikumpulkan kemudian dicek keabsahannya dengan triangulasi. Triangulasi dilakukan dengan cara membandingkan informasi atau data dengan cara yang berdeda. Peneliti juga menggunakan informan yang berbeda untuk mengecek kebenaran informasi tersebut. Melalui berbagai perspektif atau pandangan diharapkan diperoleh hasil yang mendekati kebenaran. Data yang dinyatakan valid melalui triangulasi akan memberikan keyakinan terhadap peneliti tentang keabsahan datanya, sehingga tidak ragu dalam pengambilan kesimpulan terhadap penelitian yang dilakukan. Selanjutnya data dikategorikan dan dipetakan berdasarkan topik penelitian. Selanjutnya data diklasifikasi dan dihubungkan dengan referensi teori rasionalitas.

\section{DAMPAK PENCEMARAN PERAIRAN BAGI PETAMBAK}

Daerah pesisir dan laut merupakan salah satu dari lingkungan perairan yang mudah terpengaruh dengan adanya buangan limbah dari darat. Wilayah pesisir yang meliputi daratan dan perairan pesisir sangat penting artinya bagi bangsa dan ekonomi Indonesia. Wilayah ini bukan hanya merupakan sumber pangan yang diusahakan melalui kegiatan perikanan dan pertanian, tetapi merupakan pula lokasi bermacam sumberdaya alam, seperti mineral, gas dan minyak bumi serta pemandangan alam yang indah, yang dapat dimanfaatkan untuk kesejahteraan manusia, perairan pesisir juga penting artinya sebagai alur pelayaran. Namun demikian perlu dipahami bahwa pesisir sebagai tempat peralihan antara darat dan laut serta wilayah pesisir ditandai adanya gradient perubahan sifat ekologi yang tajam dan karenannya merupakan wilayah yang peka terhadap gangguan akibat adanya perubahan lingkungan dengan fluktuasi di luar normal. Dari segi fungsinya wilayah pesisir merupakan zona penyangga bagi hewan hewan migrasi. Akibat pengaruh aktivitas manusia yang meningkat seperti pencemaran minyak hasil kegiatan eksploitasi tambang minyak di lepas pantai serta transportasi minyak, pembuangan limbah permukiman dan industri, perairan pesisir akan mengalami tekanan (stress), yang cenderung mengarah pada menurunnya kualitas lingkungan wilayah pesisir terganggu keseimbangan alami. Apalagi ditambah dengan penangkapan ikan yang berlebihan dan pengrusakan ekosistem karang secara fisik. Kerusakan fisik pada habitat sumberdaya hayati di wilayah pesisir dan lautan sepintas disebabkan oleh pengaruh alam secara murni yaitu akibat perubahan iklim global atau gejala alam lainnya seperti radiasi ultraviolet dan el nino. Namun, kalau dikaji mendalam kerusakan tersebut akibat bentuk intervensi teknologi (Dahuri, 2003).

Akibat pencemaran perairan, petambak sudah mengeluhkan penurunan pendapatan hasil usaha tambak. Data produksi perikanan air payau kecamatan Ujung Pangkah menunjukkan adanya penurunan produksi (udang maupun bandeng) pada setiap tahunnya (Gambar 1 dan Gambar 2). Pada tahun 2010, produksi udang turun sebanyak 76 ton dari tahun 2009 dan pada tahun 2011, produksi udang juga turun sebanyak 51 ton dari tahun sebelumnya. Penurunan produksi juga terjadi pada bandeng. Pada tahun 2010, produksi bandeng turun sebanyak 405 ton dari tahun 2009. Produksi bandeng tahun 2011 juga mengalami penurunan sebanyak 86 ton dari tahun 2010 (Dinas Kelautan, Perikanan dan Peternakan Kabupaten Gresik, 2011).

Informasi yang diperoleh, petambak mulai nganalisis penyebab kondisi perairan yang telah tercemar. Petambak menuduh tercemarnya lingkungan pesisir berasal dari adanya operasi produksi perusahaan migas yang ada di desanya yaitu PT. Hess Indonesia Ltd. karena memang cuma satu-satunya perusahaan itu yang ada di desa. Menurut petambak, Gresik memang memiliki banyak industri yang berkontribusi pada pencemaran perairan. Namun, keberadaan industri tersebut sudah lama dan dirasa tidak terlalu berkontribusi besar pada pencemaran air karena posisi industri tersebut berada sekitar $60 \mathrm{~km}$ dari desa. Selain itu, kawasan industri-industri yang beroperasi di sekitar pusat kota Gresik memiliki saluran pembuangan limbah yang berbeda dengan saluran air petambak.

Petambak meresahkan kegiatan migas PT. Hess ini, hal tersebut tampak pada awal kegiatan yaitu penanaman pipa-pipa yang melewati tambak dan saluran air mereka. Meskipun perusahaan ini telah memberi ganti rugi pada petambak yang lahan tambaknya terlewati pipa gas. Namun, ketakutan akan bocornya pipa gas selalu membayangi pikiran mereka yang menyebabkan adanya perubahan aktivitas 


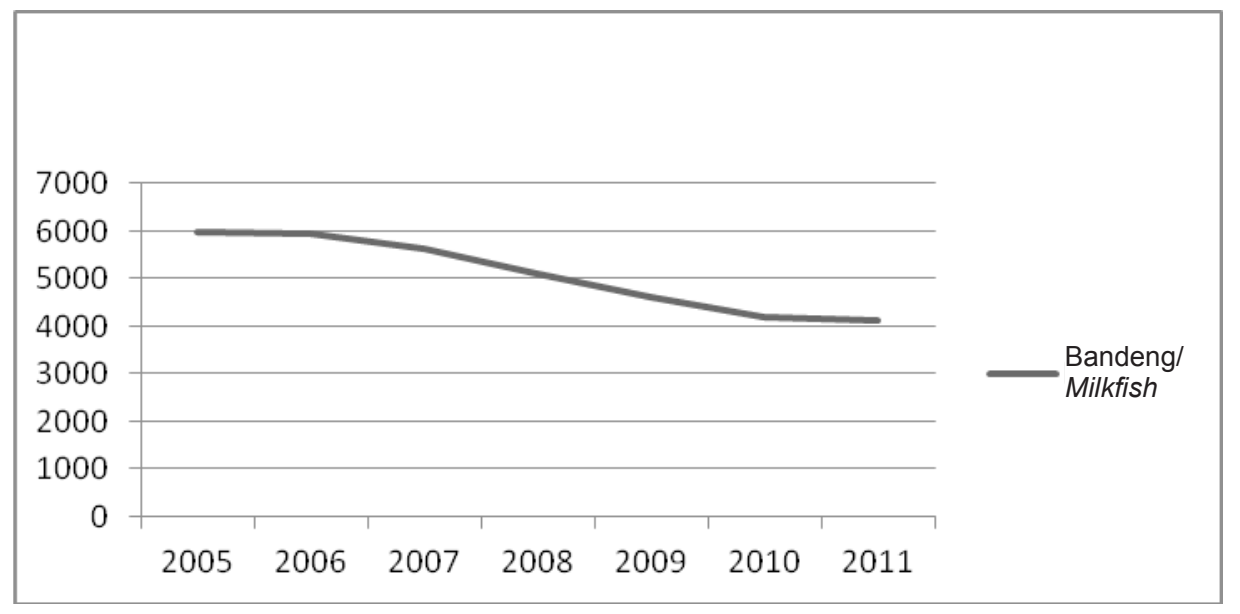

Gambar 1. Grafik Produksi Bandeng tambak Air Payau di kecamatan Ujung Pangkah, Gresik Pada Tahun 2005 - 2011.

Figure 1. Milkfish Production Graph of Brackiswater Pond in the Ujung Pangkah Sub District, Gresik in the Year 2005 - 2011.

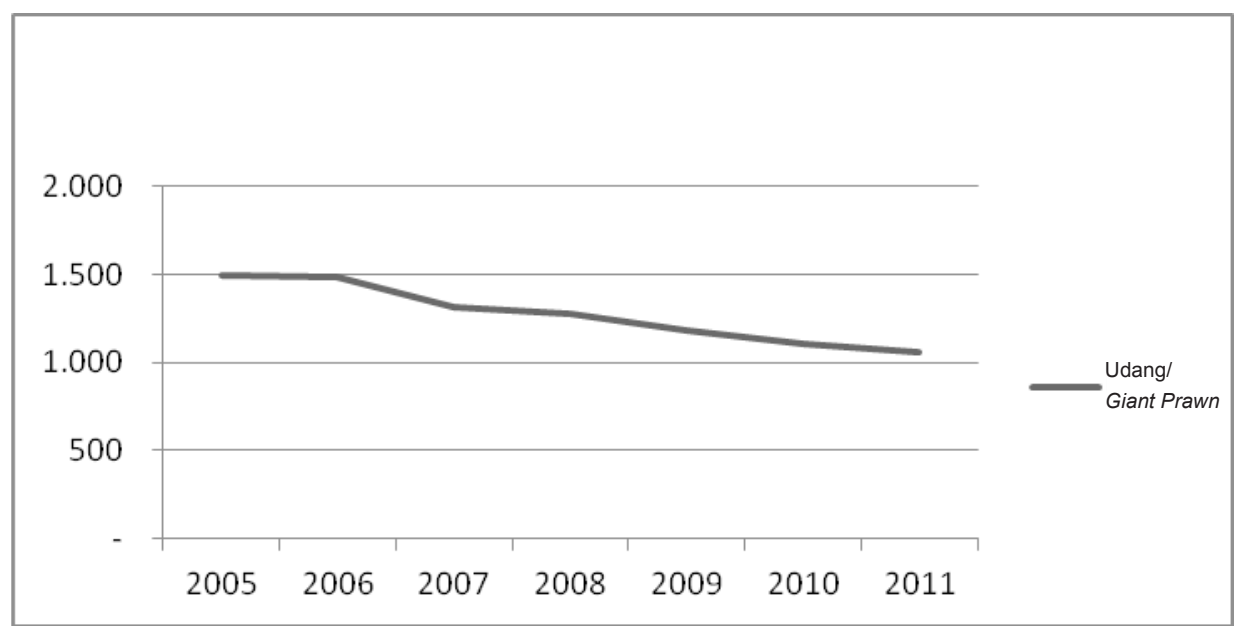

Gambar 2. Grafik Produksi Udang Tambak Air Payau di Kecamatan Ujung Pangkah, Gresik Pada Tahun 2005 - 2011.

Figure 2. Giant Prawn Production Graph of Brackiswater Pond in the Ujung Pangkah Sub District, Gresik in the Year 2005 - 2011.

budidaya petambak, terlebih pada volume penanaman benih udang-bandeng. Begitu juga frekuensi penanaman dan lama pemeliharaan, dalam setahun petambak hanya melakukan 2 kali dengan lama pemeliharaan sekitar 100 hari. Padahal, biasanya frekuensi usaha sebanyak 3 hingga 4 kali dalam setahun dengan lama pemeliharaan sekitar 120 hari. Pun juga pemeliharaan udang sekarang menggunakan pakan, padahal sebelumnya tidak menggunakan pakan. Hal tersebut karena menurunnya pakan alami dari perairan sehingga untuk memenuhi kebutuhan budidaya harus menggunakan pakan buatan.

\section{MUNCULNYA SOLIDARITAS PETAMBAK}

Fenomena dampak buruk dari aktivitas pengeboran migas PT Hess Indonesia-Pangkah, Ltd. telah menimbulkan tindakan-tindakan para petambak dalam upaya melindungi usaha tambaknya (strategi mempertahankan usaha). Awal tindakan yang dilakukan petambak adalah melakukan interaksi dengan sesama petambak. Interaksi tersebut dilakukan secara non formal berupa percakapan atau diskusi bebas seperti percakapan pada waktu istirahat di rumah jaga tambak, percakapan saat pulang bersama dari tambak, percakapan bebas di warung kopi dan 
lainnya. Kegiatan tersebut digunakan sebagai tindakan atau strategi untuk melakukan pendekatan dalam rangka membangun kebersamaan petambak. Bruce (2000) dalam Susilo (2009) menjelaskan bahwa hampir setiap perubahan kondisi lingkungan mau tidak mau menghadirkan konflik sebagai konsekuensinya. Konflik sosial dalam bidang lingkungan terjadi karena banyak faktor, diantaranya:

a. Perbedaan pengetahuan dan pemahaman tentang rusak/ tidaknya lingkungan

b. Perbedaan nilai tentang pemanfaatan lingkungan.

c. Perbedaan kepentingan yang disebabkan ketidaksamaan posisi/jabatan.

d. Persoalan pribadi, latar belakang, sejarah dan motivasi balas dendam.

Hasil penelitian Wahyudi mengenai formasi dan struktur gerakan sosial petani di Kalibakar Kabupaten Malang menjelaskan bahwa gerakan petani merupakan bagian dari gerakan sosial yang hanya menghendaki dilakukannya perubahan atas sebagaian nilai atau norma yang ada. Gerakan petani dapat berorientasi pada persoalan-persoalan ekonomi, dan kebutuhan materi lain juga dapat terkait dengan nilai-nilai dan isu-isu modern seperti: HAM, keadilan, persamaan hak, lingkungan hidup, perdamaian, dll. Sumber gerakan petani berasal dari sebagai akibat dari berbagai faktor, yakni: 1) komersialisasi lahan pertanian, 2) ketidakadilan dan penindasan yang sudah tidak bisa ditolerir, serta lonjakan biaya hidup akibat krisis ekonomi, 3) meluasnya peranan negara dalam proses transformasi pedesaan melalui revolusi hijau, 4) kebijakan yang tidak adil, perubahan sosial yang sangat cepat, dan kemerosotan kewibawaan pemimpin tradisional, 5) ganti rugi tanah yang tidak memadai, dan munculnya isu demokrasi, 6) pengingkaran terhadap hak tradisional petani, 7) sistem pengelolaan tanah yang hanya menguntungkan penguasa dan kroninya, dan 8) model penggusuran yang tidak tepat.

Masyarakat petambak desa Pangkah Wetan sudah memiliki kelompok petambak sebagai wadah organisasinya. Kelompok ini merupakan kumpulan para petambak yang didasarkan atas kesamaan, keserasian satu lingkungan sosial budaya untuk mencapai tujuan yang sama. Di desa Pangkah Wetan, terdapat 5 kelompok petambak yang masingmasing beranggotakan 18 - 25 orang. Menurut petambak, awal pembetukan kelompok tani tambak ini sebenarnya merupakan wadah belajar mengajar bagi anggotanya guna meningkatkan pengetahuan dan ketrampilan dalam usaha tambak sehingga mampu meningkatkan produktivitas dan mencapai kehidupan yang sejahtera.

Sejak adanya rencana pembangunan fasilitas produksi perusahaan migas, para petambak merasa ada ancaman terhadap terganggunya kerusakan lingkungan tambak (terutama pencemaran perairan) sehingga memunculkan rasa kebersamaan sesama petambak. Wujud kebersamaan petambak adalah terbentuknya 1 kelompok petambak desa Pangkah Wetan yang merupakan penggabungan dari 5 kelompok petambak yang telah ada. Kelompok petambak desa ini merupakan tempat memperkuat kerjasama sesama petambak dengan pihak lain. Mereka sepakat melakukan complain mengenai keberadaan dan aktivitas perusahaan. Demi menguatkan kebersamaan, kelompok petambak desa Pangkah Wetan bekerjasama dengan kelompok petambak desa Pangkah Kulon yang juga merupakan gabungan dari 7 kelompok kecil petambak. Melalui kerjasama ini diharapkan usahanya akan lebih efisien serta lebih mampu menghadapi ancaman, tantangan, hambatan dan gangguan dari pihak lain.

Adanya konsekuensi logis dari tekanan kerusakan lingkungan, dalam kasus ini pencemaran air, yang dialami petambak telah mempengaruhi pola-pola interaksi sosialnya. Secara sosial, dampak pencemaran air telah membangkitkan solidaritas petambak untuk bersatu dalam upaya penyelesaian masalah yang dihadapi. Terbukti dengan adanya tindakan aksi petambak akibat dari pembangunan fasilitas dan beroperasinya produksi migas dari PT Hess Indonesia Pangkah Ltd karena dianggap telah mencemari perairan tambak. Adanya anggapan pencemaran air oleh perusahaan tersebut telah memunculkan kebersamaan petambak dengan melalui interaksi informal antar petambak. Kebersamaan petambak memiliki tujuan yaitu menghentikan, mencegah atau membalikkan perubahan yang dihasilkan dari proses aktivitas perusahaan migas tersebut (kemerosotan kualitas lingkungan alam) kepada kondisi lingkungan yang baik.

Kebersamaan kelompok ini jika dilihat dari perspektif Scott (1994) merefleksikan tingkat komunalitas sebuah masyarakat petambak. Tingkat komunalitas yang tinggi merupakan media yang paling baik untuk mendistribusikan resiko sehingga dapat mencegah atau menunda resiko 
krisis-krisis subsisten lebih lanjut. Dari sini dapat dikatakan bahwa semakin tinggi tingkat komunalitas maka tingkat kerentanan sosial semakin rendah. Ketidakpastian-ketidakpastian dalam usaha tambak dapat ditekan seminimal mungkin. Dan menurut Mustain (2007) bahwa solidaritas kolektif komunitas memobilisasi gerakan pertentangan yang efektif dalam melahirkan kekuatan menggerakkan massa. Ikatan kolektif disadari sebagai dasar pembentukan kesadaran bersama terhadap masalah bersama. Scott (1994) juga mengungkapkan bahwa tekanan kerawanan ekologi, sistem harga dan monokultur akan yang merupakan rutinitas subsistensi mendorong petambak untuk melakukan protes atau perlawanan yang menekan itu.

\section{GERAKAN SOSIAL PETAMBAK}

Solidaritas petambak yang tumbuh akibat tekanan pencemaran perairan tambak, telah membentuk ikatan komunal petambak dalam satu wadah yaitu kelompok tani tambak desa Pangkah Wetan. Dalam wadah ini, petambak menyatukan aspirasinya dengan menentukan strategi-strategi gerakan-gerakan perlawanannya. Gerakangerakan yang mereka lakukan lebih terorganisir dan lebih berani menunjukkan identitas kolektif mereka. Berbeda dengan hasil penelitian James Scott, dimana para petani cenderung melakukan perlawanan yang tidak menarik perhatian orang dan bersembunyi di balik anonimitas mereka. Bentuk khas perlawanan mereka lebih bersifat diam-diam dan kontra perampasan. Sebaliknya, dalam perkembangan selanjutnya petani lebih berani menunjukkan sikap mereka, bahkan berani membakar tebu mereka sendiri walaupun itu juga beresiko.

Menurut Sunarto (2004), dalam sosiologi, gerakan petambak disebut sebagai suatu bentuk perilaku kolektif tertentu yang diberi nama gerakan sosial. Gerakan sosial adalah aktivitas sosial berupa gerakan sejenis tindakan sekelompok yang merupakan kelompok informal yang berbetuk organisasi, berjumlah besar atau individu yang secara spesifik berfokus pada suatu isu-isu sosial atau politik dengan melaksanakan, menolak, atau mengkampanyekan sebuah perubahan sosial. Gerakan sosial berbeda dengan perilaku kolektif karena gerakan sosial ditandai dengan adanya tujuan atau kepentingan bersama.
Terorganisirnya gerakan petambak terlihat dari adanya koordinasi dengan kelompokkelompok masyarakat lain yang juga merasakan dampak pencemaran perairan antara lain kelompok petambak, kelompok nelayan dari desa lain. Hasil koordinasi tersebut menghasilkan aliansi untuk memudahkan komunikasi dan kebutuhan wadah aspirasi yang diberi nama Aliansi 4 Pemerintahan Desa (A4PD). Aliansi ini bentukan kerjasama dari empat desa di kecamatan Ujung Pangkah yaitu desa Pangkah Wetan, Pangkah Kulon, Banyuurip dan Ngimboh. Pengurus A4PD yang dipimpin langsung oleh masing-masing Kepala Desa melakukan komunikasi dengan pemerintah kabupaten dan pihak perusahaan, mereka meminta aktivitas pembangunan lapangan migas dihentikan karena dianggap berdampak pada produktivitas tambak dan hasil tangkapan serta warga sekitar. Namun PT. Hess Indonesia - Pangkah Ltd. terus melakukan pembangunan fasilitas produksi minyak dan gas di Lapangan Ujung Pangkah dan aktif berproduksi sejak April 2007, hal ini meningkatkan amarah para petambak. Melihat kenyataan aktivitas produksi migas terus dilakukan maka para petambak melakukan aksi demonstrasi. Demonstrasi tidak hanya ditujukan pada perusahaan migas melainkan juga pada pemerintah kabupaten Gresik, yang menurut petambak telah berpihak pada perusahaan migas dengan memberikan ijin produksi didaerah Pangkah. Hasil dari aksi protes ini, seluruh warga desa termasuk didalamnya petambak akan mendapatkan dana community development (dana kemasyarakatan dengan program kemitraan dan bina lingkungan) dari perusahaan.

Aksi protes juga ditunjukkan warga pada hari kamis, tanggal 15 November 2007 yang berbarengan dengan rencana operator Blok Pangkah, Hess (Indonesia-Pangkah) Ltd, meresmikan Lapangan Ujungpangkah (onshore processing facility) di Kawasan Industri Maspion (KIM) oleh Menteri ESDM (Purnomo Yusgiantoro). Petambak dan nelayan melakukan aksi demo dengan cara memblokir jalur Pantura Lamongan-Surabaya selama 30 menit. Sembari menutup akses masuk kawasan industri itu, warga membentangkan spanduk yang berbunyi "Tutup Hess" dan "Kami bosan dengan janji-janji Hess". Aksi unjuk rasa oleh sedikitnya 2.500 warga dari tiga desa di Kecamatan Pangkah dilakukan sejak pukul 09.00 WIB. Menurut petambak, aksi demonstrasi dipicu oleh beberapa alasan yaitu polusi migas, perusahaan migas dianggap tidak menghargai 
tradisi dan kultur warga serta keberadaannya tidak membuat warga sejahtera. Petambak mencontohkan mengenai dana kompensasi yang dijanjikan perusahaan kepada masyarakat tidak terpenuhi hingga saat aksi demo dilakukan. Akhirnya pada akhir bulan November tahun 2007 perusahaan menepati janjinya dengan memberikan dana kemasyarakatan tahap awal sebesar Rp 300 juta.

Pergolakan warga termasuk petambak muncul lagi dan pada hari senin, 4 Mei 2009 melakukan aksi protes lagi. Sekitar 400an warga yang tergabung dalam Aliansi 4 Pemerintahan Desa (A4PD) Kecamatan Ujung Pangkah berunjuk rasa mendatangi gedung DPRD Gresik. Aksi tersebut diterima oleh Wakil Ketua DPRD Gresik dan yang mewakili warga adalah koordinator umum A4PD (SM). SM menyampaikan bahwa warga menuding perusahaan tidak transparan dalam menyalurkan dana community development (comdev). Selama ini penyaluran dana comdev tidak melibatkan pemerintahan desa dan justru dianggap sering memicu konflik antarkelompok. Menurut SM yang juga Kades Pangkah Wetan, perusahaan menganak-emaskan kelompok tertentu saat menyalurkan dana. Karena pemerintah desa tidak pernah dilibatkan saat Hess merealisasikan dana comdev, jika program ini menuai kegagalan, pemerintah desa yang jadi sasaran kemarahan warga. Selama ini kelompok petambak terabaikan, petambak pernah dijanjikan dana stimulan Rp 75 juta, namun hingga kini belum ada.

Pada hari kamis (tanggal 7 November 2011), petambak dan nelayan dari desa Pangkahkulon, Pangkahwetan, Banyurip, dan Ngemboh Kecamatan Ujungpangkah Gresik melakukan aksi protes lagi ke Kantor Hess Indonesia Pangkah Ltd. Aksi protes ini didukung adanya tumpahan minyak mentah yang terjadi pada tanggal 30 Oktober 2011. Tumpahan minyak berupa gumpalan lumpur yang mengapung di laut ini diketahui pertama kali oleh nelayan desa Pangkah Wetan. Perairan laut merupakan sumber perairan bagi tambak dan lokasi penangkapan nelayan. Sejak ada tumpahan minyak, petambak menginformasikan bahwa udang dan bandeng mengalami kematian setelah dua hari ditanam. Petambak juga mengeluhkan kerusakan tambak karena hutan bakau mengalami kerusakan bahkan mati. Padahal manfaat dari hutan bakau bagi tambak adalah :
1. Kontruksi pematang tambak menjadi lebih kuat karena terpegang akar-akar bakau.

2. Keanekaragaman hayati akan meningkat (termasuk bibit ikan alam dan kepiting), yang akan meningkatkan juga pendapatan pembudidaya ikan.

3. Kualitas air tambak menjadi lebih baik, karena fungsi perakaran bakau dapat 'menyaring' limbah padat dan mikroba yang terdapat pada lantai hutan bakau dan dapat mendekomposisi bahan organik yang berasal dari kegiatan budidaya maupun dari luar tambak.

4. Terciptanya sabuk hijau pesisir (coastal green belt) serta ikut mendukung program mitigasi dan adaptasi perubahan iklim global karena bakau akan mengikat (sequester) $\mathrm{CO}_{2}$ dari atmosfer dan melindungi kawasan pemukiman dari kecenderungan naiknya muka air laut.

5. Bakau akan mengurangi dampak bencana alam seperti badai dan gelombang air pasang, sehingga kegiatan-kegiatan usaha maupun pemukiman disekitarnya dapat terselamatkan.

6. Mencegah erosi pantai dan intrusi air laut ke darat, sehingga pemukiman dan sumber air tawar dapat terjaga dan dipertahankan.

7. Pejalan kaki akan nyaman berjalan di atas pematang karena dirimbuni tajuk tanaman bakau.

8. Daun bakau dapat digunakan sebagai makanan untuk ternak (khususnya, kambing), dan buahnya dapat dijadikan berbagai macam penganan manusia (seperti selai, kripik dll). (http://www. indonesia.wetlands.org)

Selama ini, masyarakat Ujung Pangkah merasa tidak puas atas mediasi dari beberapa kali demo yang telah dilakukan. Pada unjuk rasa (7 November 2011) di kantor DPRD (Dewan Perwakilan Rakyat Daerah) yang berlanjut ke kantor Bupati, para pengunjuk rasa diterima Wabup di kantornya, yang kemudian dilakukan mediasi dengan wakil Perusahaan Hess. Pada saat itu Wakil Bupati Gresik, Mohammad Qosim, memerintahkan untuk menginventarisir semua kerugian masyarakat yang disinyalir akibat tumpahan minyak di perairan lepas pantai Ujung 
Pangkah. Wakil Bupati juga meminta BPMP (Badan Penanaman Modal dan Perijinan) untuk meneliti kembali seluruh perizinan perusahaan pengeboran minyak asal Amerika Serikat tersebut. Begitu juga BLH (Badan Lingkungan Hidup) diamanatkan untuk meneliti persoalan pencemaran minyak mentah di perairan utara Gresik yang diduga disebabkan oleh kebocoran pipa bawah laut milik PT. Hess Pangkah Indonesia. Kedua belah pihak tidak keberatan dengan masukan wakil bupati.

Zubir (2002) menjelaskan bahwa dalam melihat gerakan sosial, terdapat dua bentuk yaitu pertama pola struktural dan kedua pola non struktural. Dalam pola struktural, resistensi yang dilakukan adalah terhadap pengusaha atau penguasa. Secara struktural, ada kelompok lain yang sifatnya menindas. Susilo (2009) juga menjelaskan bahwa banyak akibat yang muncul dari bentuk struktur konflik semacam ini. Karena pemerintah berpihak pada perusahaan/investor, tidak jarang kepentingan masyarakat cenderung dikesampingkan.

Dalam realitas sosial, ada kepentingan yang bersifat mutualisme antara penguasaha dan 'penguasa' seperti dalam gagasan sosiolog Peter M. Blau, yaitu semacam pertukaran simetris. Terutama ditentukan oleh kebutuhan pengusaha kepada pemerintah karena regulasi-regulasi yang dihasilkan amat dibutuhkan demi mempermudah 'birokrasi' bisnis mereka. Sementara itu bagi pemerintah, kehadiran pengusaha lebih dilihat sebagai pembawa 'rezeki' melalui perijinan, retribusi dan pajak yang harus mereka bayarkan. Pendapatan pemerintah lokal akan terisi secara rutin dari keberadaan pengusaha ini. Akar persoalannya ditemukan tidak jauh dari kebutuhan hidup ekonomis manusia. Akibat eksploitasi dengan tidak memikirkan daya dukung yang dimiliki, lingkungan pun akhirnya terkorbankan. Telah menjadi masalah yang sudah dapat dipastikan bahwa akibat overexploitation dan kurang memperhatikan aspek keberlanjutan. Kendati secara ekonomi dapat meningkatkan nilai jual, namun di sisi lain juga bisa menimbulkan ancaman kerugian ekologi yang jauh lebih besar, seperti hilangnya lahan, langkanya air bersih, banjir, longsor, dan sebagainya.

Menurut Susilo (2009), manusia tidak hanya menerima pengaruh dari lingkungannya, tetapi juga memberikan pengaruh yang semakin lama semakin besar terhadap alam. Kehadiran manusia semakin memperkaya proses dinamis bumi yang sudah berlangsung sejak awal keberadaannya.
Kemampuan otak manusia dalam menemukan pemikiran-pemikiran baru untuk menemukan teknologi yang semakin beragam membawa dampak pengaruh besar terhadap alam. Dapat dikatakan bahwa bumi tidak lagi mengalami proses dinamis tersebut pada dirinya sendiri, melainkan sudah melibatkan manusia dan mahlukmahluk hidup dalam proses interaksi yang saling mempengaruhi. Pengaruh tersebut akan semakin besar sejalan dengan berjalannya waktu. Hanya saja peran dan pengaruh yang ditunjukkan manusia terhadap alam tidak membantu alam berkembang kearah kesempurnaan. Intervensi manusia telah membawa dampak negatif terhadap alam, dan berbagai lapisan kehidupan didalamnya.

\section{PERGOLAKAN SEBAGAI RASIONALITAS PETAMBAK}

Aksi penolakan terhadap pembangunan dan aktivitas perusahaan migas oleh petambak dijelaskan Wahyudi (2005) disebut gerakan petani yang merupakan salah satu jenis dari gerakan sosial, artinya gerakan sosial yang dilakukan petani (dalam hal ini adalah petambak). Gerakan sosial merupakan gerakan yang dilakukan oleh sekelompok orang secara kolektif, kontinyu dan atau sistematis dengan tujuan untuk mendukung atau menentang keberlakuan tata kehidupan tertentu, dimana mereka memiliki kepentingan didalamnya, baik secara individu, kelompok, komunitas, atau level yang lebih luas lagi. Gerakan ini bukan sekedar suatu reaksi tetapi juga sebagai wahana untuk mencapai tujuan-tujuan perubahan yaitu lingkungan tambak yang memiliki daya dukung tinggi.

Aksi protes yang dilakukan petambak merupakan bentuk resistensi petambak terhadap kebijakan pemerintah dan pengusaha. Mustain (2007) menjelaskan bahwa resistensi petani merupakan suatu reaksi defensif akibat tidak terjaminnya kehidupan petani. Dengan tidak terjaminnya kehidupan petani, maka perilaku resistensi tersebut dipakai sebagai survival strategy dalam menghadapi ketidakpastian (uncertainty). Perilaku ini bukan saja menggambarkan tindakan pengingkaran petani terhadap pemegang kebijakan yaitu negara, melainkan juga menjadi pertanda aksi di tengah tidak terjaminnya kehidupan mereka jika terus mengamini kebijakan negara yang hegemoni dan tidak pernah menguntungkan petani kecil. Menurut Popkin (1986) di pedesaaan Asia gerakan petani di masa kolonial, menunjukkan tiga faktor 
utama yang menimbulkan kemarahan kaum petani pedesaan, yaitu perubahan struktur agraria, meningkatnya eksploitasi, dan kemorosotan status sosial.

Resistensi petambak sebenarnya didasari oleh pertimbangan rasional individu para petambak terhadap perubahan yang dikalkulasi akan merugikan dan bahkan mengancam mereka, atau sekurang-kurangnya, perubahan itu dinilai menghalangi usaha yang telah mereka lakukan demi meningkatkan taraf hidup. Dengan mengacu pada perspektif Popkin mengenai tindakan masyarakat petambak yang didasari atas pijakan yang rasional yaitu alasan petambak melakukan aksi protes tersebut. Perspektif Popkin lebih sesuai dibandingkan dengan perpektif Scott dikarenakan konteks aksi protes yang diakukan oleh petambak lebih pada aksi tindakan yang rasional bukan atas dorongan moral atau tradisi yang itu bertentangan dengan kultur masyarakat. Juga bukan didasarkan atas keyakinan agama atau kepercayaan tertentu yang itu bertentangan atau bergesekan dengan nilainilai di masyarakat tetapi aksi tersebut lebih dekat dengan pilihan atau pertimbangan yang rasional untuk bertindak, yaitu harapan mendapatkan kondisi lingkungan tambak yang akan memberikan keuntungan usaha yang maksimal.

Jika aksi tersebut dilihat dari sudut pandang Scott (2000), maka kurang sesuai pada konteks permasalahan penelitian. Pertama karena masalah yang menjadi pemicu timbulnya aksi bukan disebabkan pergeseran budaya setempat oleh tindakan atau pengaruh dari luar tetapi lebih pada akses lingkungan perairan pantai (tambak) dan desa yang lebih dekat dengan keinginan petambak untuk mendapatkan fasilitas usaha yang memadai dari pemerintah sehingga aksi petambak lebih menginginkan perubahan yang lebih baik secara materiil bukan mempertahankan tradisi yang telah ada. Kedua karena aksi yang dilakukan petambak tidak individual tetapi kelompok ataupun secara kelompok tetapi tidak sembunyi-sembunyi yang dilakukan secara terang-terangan dengan membawa sejumlah poster tentang kritik dan tuntutan dari petambak kepada pemerintah daerah dan perusahaan migas. Situasi tersebut berujung pada adanya komunikasi yang menghasilkan kesepakatan antara petambak, pemerintah dan perusahaan.

Dari penjelasan tentang tindakan protes oleh petambak menunjukkan bahwa para petambak beranimengungkapkan tindakannya secara terbuka, yaitu tindakan yang secara langsung memprotes atau melawan secara fisik. Alasan utama petambak melakukan tindakan protes tersebutadalah berkaitan dengan kelangsungan hidup usaha tambak dan kehidupan mereka. Dengan tindakan tersebut mereka berharap tetap bisa melakukan aktivitas usaha tambaknya dengan perolehan keuntungan maksimal. Pemilihan tindakan ini bukanlah hanya merupakan pilihan yang tidak berdasar, tetapi pilihan ini cenderung merupakan pilihan rasional dari hasil pengamatan dan pengalaman seharihari dilapangan yang mereka anggap berdampak pada usaha tambaknya. Aksi protes tersebut merupakan alternatif pilihan yang paling rasional untuk merumuskan artikulasi kepentingan atas subsistensi, serta mencari alternatif lain demi mengamankan batas subsistensi para petambak.

\section{PENUTUP}

Adanya pencemaran perairan yang terjadi di lingkungan tambak, telah mengakibatkan penurunan produksi tambak yang selanjutnya akan menurunkan pendapatan petambak. Pencemaran perairan terjadi akibat aktivitas perusahan migas PT Hess Indonesia-Pangkah,Itd. karena hanya perusahaan ini yang ada di kecamatan Ujung Pangkah. Pergolakan muncul dalam masyarakat petambak karena adanya konsekuensi logis dari tekanan kerusakan lingkungan, dalam kasus ini pencemaran air. Situasi ini telah mempengaruhi pola-pola interaksi sosial masyarakat petambak. Hal ini telah membangkitkan solidaritas petambak untuk bersatu dalam upaya penyelesaian masalah yang dihadapi dan memunculkan gerakan sosial melawan perusahaan dan pemerintah.

Gerakan sosial yang dilakukan petambak berupa gerakan terbuka melalui aksi demonstrasi. Hal ini dilakukan sebagai tindakan protes petambak kepada perusahaan dan pemerintah yang tidak pernah sejalan dengan petambak. Gerakan sosial ini adalah bentuk kemarahan petambak akibat merosotnya pendapatan yang disebabkan aktivitas perusahaan dan pemerintah yang telah memberikan ijin usaha bagi perusahaan. Resistensi petambak didasari oleh pertimbangan rasional individu para petambak terhadap perubahan yang dikalkulasi akan merugikan dan bahkan mengancam mereka, atau sekurangkurangnya, perubahan itu dinilai menghalangi usaha yang telah mereka lakukan demi meningkatkan taraf hidup. 
Kenyataan bahwa gerakan sosial yang dilakukan petambak desa Pangkah Wetan bertujuan untuk memulihkan kembali daya dukung lingkungan tambak. Untuk itu perlu adanya tindakan perbaikan lingkungan yang berorientasi lestari. Seharusnya dana pengembangan masyarakat yang diberikan perusahaan (dana CSR) tidak berupa fisik karena sifatnya cepat habis dan tidak berbentuk sesuatu yang bernilai manfaat bersama. Pemberian secara fisik juga akan memunculkan permasalahan sosial lainnya dalam masyarakat. Contoh bentuk pemberian dana pengembangan masyarakat dengan bentuk lain seperti :

Perbaikan saluran perairan yang mengairi tambak, perusahaan dapat bekerjasama dengan Lembaga-lembaga pengabdian masyarakat Perguruan Tinggi atau lembaga-lembaga swadaya masyarakat untuk pengelolaannya. Selain itu juga memanfaatkan peran dan fungsi lembaga-lembaga tersebut dalam masyarakat petambak. Khususnya peran sebagai lembaga pendamping masyarakat, yang berfungsi memberikan pelatihan-pelatihan (teknis dan enterpreunership), support informasi, maupun penyelesaian permasalahan dalam masyarakat.

Perusahaan dapat bekerjasama dengan koperasi dalam pengelolaan dana pengembangan masyarakat. Dana tersebut dapat dijadikan modal koperasi desa dengan tujuan untuk menghidupkan koperasi dan meningkatkan perekonomian masyarakat.

Bagi Pemerintah Kabupaten, keberadaan perusahaan migas ini dapat menambah pendapatan daerah, namum Pemerintah Kabupaten Gresik juga harus memperhatikan kesejahteraan masyarakatnya. Pada kasus aksi ini, pemerintah harus menjembatani atau berlaku sebagai mediasi antara masyarakat dengan perusahaan untuk menyelesaikan permasalahan yang penyelesaiaannya dapat diterima oleh keduanya. Perlu adanya kebijakan pemerintah yang pro rakyat seperti peninjauan kembali ijin perusahaan oleh BPMP (Badan Penanaman Modal dan Perijinan) dan penyelesaian pencemaran oleh BLH (Badan Lingkungan Hidup).

Keberadaan perusahaan migas di desa Pangkah Wetan, kecamatan Ujung Pangkah Kabupaten Gresik diharapkan dapat meningkatkan perekonomian masyarakat. Namun, disisi lain perusahaan ini menjadi ancaman bagi masyarakat petambak yang memunculkan pergolakan (gerakan sosial). Gerakan sosial memiliki unsur kepentingan yang berkaitan dengan persoalan ekonomi petambak yaitu terganggunya sistem usaha tambak akibat pencemaran perairan. Perilaku tersebut menggambarkan tindakan pengingkaran petambak terhadap kebijakan pemerintah dan sebagai aksi terhadap tidak terjaminnya kehidupan usaha tambak.

\section{DAFTAR PUSTAKA}

Anonymous. 2013. Manfaat Hutan Bakau Bagi Tambak. http://www.indonesia.wetlands.org. Diakses pada tanggal 5 Februari 2013).

Badan Pusat Statistik. 2011. Gresik Dalam Angka tahun 2010. Kabupaten Gresik.

Dahuri, R. 2003. Keanekaragaman Hayati Laut:Aset Pembangunan Berkelanjutan Indonesia. Jakarta: Gramedia Pustaka Utama.

Dinas Kelautan, Perikanan dan Peternakan Kabupaten Gresik. 2011. Statistik Perikanan Gresik Tahun 2005 -2011. Kabupaten Gresik.

Moleong, L. J. 2008. Metodologi Penelitian Kualitatif (edisi revisi). Jakarta: Remaja Rosdakarya.

Mulyana, D. 2004. Metodologi Penelitian Kualitatif : Paradigma Baru IImu Komunikasi dan Ilmu Sosial Lainnya. Bandung: PT Remaja Rosdakarya.

Mustain. 2007. Petani vs Negara: Gerakan Sosial Petani Melawan Hegemoni Negara. Yogyakarta: Ar Ruzz Media.

Paige, J. M. 2004. Revolusi Agraria: Gerakan Sosial Dan Pertanian Ekspor Di Negara-Negara Dunia Ketiga. Terjemahan: Abdul Mukhit Dan Izzul Mustofa. Pasuruan: Penerbit Pedati.

Popkin, S. L. 1986. Memahami Petani Secara Rasional. Jurnal Prisma. 9: 65-72.

Scott, J. C. 2000. Senjatanya Orang-Orang yang Kalah: Bentuk-Bentuk Perlawanan Sehari-hari Kaum Tani. Cetakan I. Jakarta: Yayasan Obor Indonesia.

1994. Moral Ekonomi Petani: Pergolakan dan Subsistensi di Asia Tenggara. Jakarta: LP3ES.

Sunarto, K. 2004. Pengantar Sosiologi. Jakarta: Lembaga Penerbit Fakultas Ekonomi Universitas Indonesia.

Susilo, D.R.K. 2009. Sosiologi Lingkungan. Jakarta: Rajawali Pers. 
Sugiyono. 2012. Nelayan Gresik Tuntut Ganti Rugi dari PT Hess. http://surabaya.tribunnews. com/2012/11/09/nelayan-gresik-tuntut-ganti-rugi-dari-pt-hess. (diakses pada tanggal 7 Desember 2012).
Wahyudi. 2005. Formasi Dan Struktur Gerakan Sosial Petani: Studi Kasus Reklaiming/ Penjarahan Atas Tanah PTPN XII (Persero) Kalibakar Malang Selatan. Malang: UMM Press.

Zubir, Z. 2002. Radikalisme Kaum Pinggiran. Yogyakarta: Insist Press. 